\title{
A Simple Method to Avoid Brain Shift during Neuronavigation: Technical Note
}

\section{Método simples para se evitar brain shift na neuronavegação: Nota técnica}

\author{
Jair Leopoldo Raso ${ }^{1 \odot}$ \\ ${ }^{1}$ Faculdade de Ciências Médicas de Minas Gerais, Instituto Mineiro de \\ Neurocirurgia, Vale do Sereno, Nova Lima, MG, Brazil \\ Arq Bras Neurocir 2021;40(1):78-81.
}

\begin{abstract}
Address for correspondence Jair Leopoldo Raso, PhD, Faculdade de Ciências Médicas de Minas Gerais, Instituto Mineiro de Neurocirurgia, Alameda Oscar Niemeyer, 400/404, Vale do Sereno, Nova Lima, MG, 34006 049, Brazil (e-mail: jraso@uol.com.br).
\end{abstract}

\begin{abstract}
Keywords

- neuronavigation

- brain shift

- surgical technique

- brain surgery
\end{abstract}

\section{Resumo}

Introduction The precise identification of anatomical structures and lesions in the brain is the main objective of neuronavigation systems. Brain shift, displacement of the brain after opening the cisterns and draining cerebrospinal fluid, is one of the limitations of such systems.

Objective To describe a simple method to avoid brain shift in craniotomies for subcortical lesions.

Method We used the surgical technique hereby described in five patients with subcortical neoplasms. We performed the neuronavigation-guided craniotomies with the conventional technique. After opening the dura and exposing the cortical surface, we placed two or three arachnoid anchoring sutures to the dura mater, close to the edges of the exposed cortical surface. We placed these anchoring sutures under microscopy, using a 6-0 mononylon wire. With this technique, the cortex surface was kept close to the dura mater, minimizing its displacement during the approach to the subcortical lesion. In these five cases we operated, the cortical surface remained close to the dura, anchored by the arachnoid sutures. All the lesions were located with a good correlation between the handpiece tip inserted in the desired brain area and the display on the navigation system.

Conclusion Arachnoid anchoring sutures to the dura mater on the edges of the cortex area exposed by craniotomy constitute a simple method to minimize brain displacement (brain-shift) in craniotomies for subcortical injuries, optimizing the use of the neuronavigation system.

Introdução A identificação precisa de estruturas anatômicas e lesões no cérebro é o principal objetivo dos sistemas de neuronavegação. Brain shift, deslocamento do cérebro após abertura das cisternas e drenagem de líquor, é uma das limitações do método.

received

April 30, 2020

accepted

July 7, 2020

published online

November 26, 2020 ISSN 0103-5355.

\footnotetext{
(c) 2020. Sociedade Brasileira de Neurocirurgia. All rights reserved. This is an open access article published by Thieme under the terms of the Creative Commons Attribution-NonDerivative-NonCommercial-License, permitting copying and reproduction so long as the original work is given appropriate credit. Contents may not be used for commercial purposes, or adapted, remixed, transformed or built upon. (https://creativecommons.org/ licenses/by-nc-nd/4.0/)

Thieme Revinter Publicações Ltda., Rua do Matoso 170, Rio de Janeiro, RJ, CEP 20270-135, Brazil
} 


\section{Palavras-chave \\ - neuronavegação \\ - brain shift \\ - técnica cirúrgica \\ - cirurgia cerebral}

Objetivo Descrever um método simples para se evitar brain shift nas craniotomias para lesões subcorticais.

Método A técnica cirúrgica descrita foi utilizada em cinco casos de pacientes portadores de neoplasias subcorticais. As craniotomias guiadas por neuronavegação foram realizadas com a técnica habitual. Após abertura da dura-máter e exposição da superfície cortical, dois ou três pontos de ancoramento da membrana aracnoide foram realizados na dura-máter, junto às bordas da superfície cortical exposta. Estes pontos de ancoramento foram feitos sob microscopia utilizando-se mononylon 6-0. Com esta técnica, a superfície do córtex era mantida junto à dura-máter, minimizando seu deslocamento durante a abordagem da lesão subcortical. Nos cinco casos em que a técnica foi utilizada, a superfície cortical permaneceu próxima à dura-máter, ancorada pelas suturas da aracnoide. Todas as lesões foram localizadas com boa correlação entre a ponteira inserida na área cerebral desejada e o registro do sistema de navegação. Conclusão Suturas de ancoramento da aracnoide na dura-máter junto às bordas da área de córtex exposta pela craniotomia constituem método simples para minimizar o deslocamento do cérebro (brain-shift) nas craniotomias para lesões subcorticais, otimizando a utilização do sistema de neuronavegação.

\section{Introduction}

Neuronavigation is a technology recently added to neurosurgical procedures for planning craniotomies and real-time pinpointing of intracranial lesions and their relationship with anatomical structures. The available systems use magnetic resonance imaging (MRI) or computed tomography (CT)-scan images taken before the procedure. ${ }^{1}$ For subcortical lesions, such references may become inaccurate because of brain displacement caused by gravity and cerebrospinal fluid (CSF) drainage. This phenomenon, brain shift, may cause the surgeon to err, which is one of the limitations of this method. The present study aimed at describing a simple method to minimize the effects of brain shift in approaches to subcortical lesions, providing the surgeon with greater safety and confidence in the use of neuronavigation.

\section{Method}

We used the technique hereby described to operate five patients with subcortical neoplasms. We performed the craniotomy according to planning, aided by neuronavigation. We used two neuronavigator models (Medtronic, Minneapolis, Minnesota, USA; BrainLab, Munich, Germany), in which the record is obtained by correlating landmarks on the patient's skin and skull, and we used a handpiece tip to obtain the point-to-point correspondence. Neuronavigation was initially used to plan the extension of the craniotomy, keeping the subcortical lesion as the central target. After removing the bone flap, we anchored the dura to the bone, using the conventional technique. We then used neuronavigation to plan the dura mater opening around the projection of the lesion. After exposing the cortical surface and before opening the arachnoid over the area chosen for corticectomy, we anchored the arachnoid to the dura, close to the edges of the exposed area, using 2 or 3 6-0 mononylon sutures under microscopy (-Fig. 1). Next, we used neuronavigation on the surface to identify the ideal point for corticectomy and the trajectory to address the subcortical lesion. Then, we opened the arachnoid at the point chosen for corticectomy. We checked the trajectory of the approach in real time using neuronavigation, until we reached the subcortical lesion. Throughout the five cases in which we used this approach, the cortical surface remained close to the dura mater, anchored by the arachnoid sutures. All the lesions were located bearing a good correlation between the handpiece tip inserted in the desired brain area and what the navigation system displayed.

\section{Discussion}

Neuronavigation is a technology already incorporated in most neurosurgery services. It assists the surgeon in planning craniotomies and in the precise location of deep lesions and their relationship with anatomical landmarks. It is also useful in providing maximum safety in lesion resections.

Neuronavigation uses the same principles as stereotaxis, based on the Cartesian coordinate system. Any point in the brain can be reached by measuring the lesion to be addressed in the horizontal, frontal and sagittal planes. The neuronavigation system provides precise surgical guidance, paralleling the measurements obtained with MRI or CT scan data from the patient. This reconstruction is displayed on a computer workstation console, placed next to the surgical field. Thus, the resonance images displayed on the screen become maps, correlating points on the scanned image with corresponding locations within the brain in real time.

In subcortical lesions, the neuronavigation system assists in choosing the corticectomy location, in planning and 


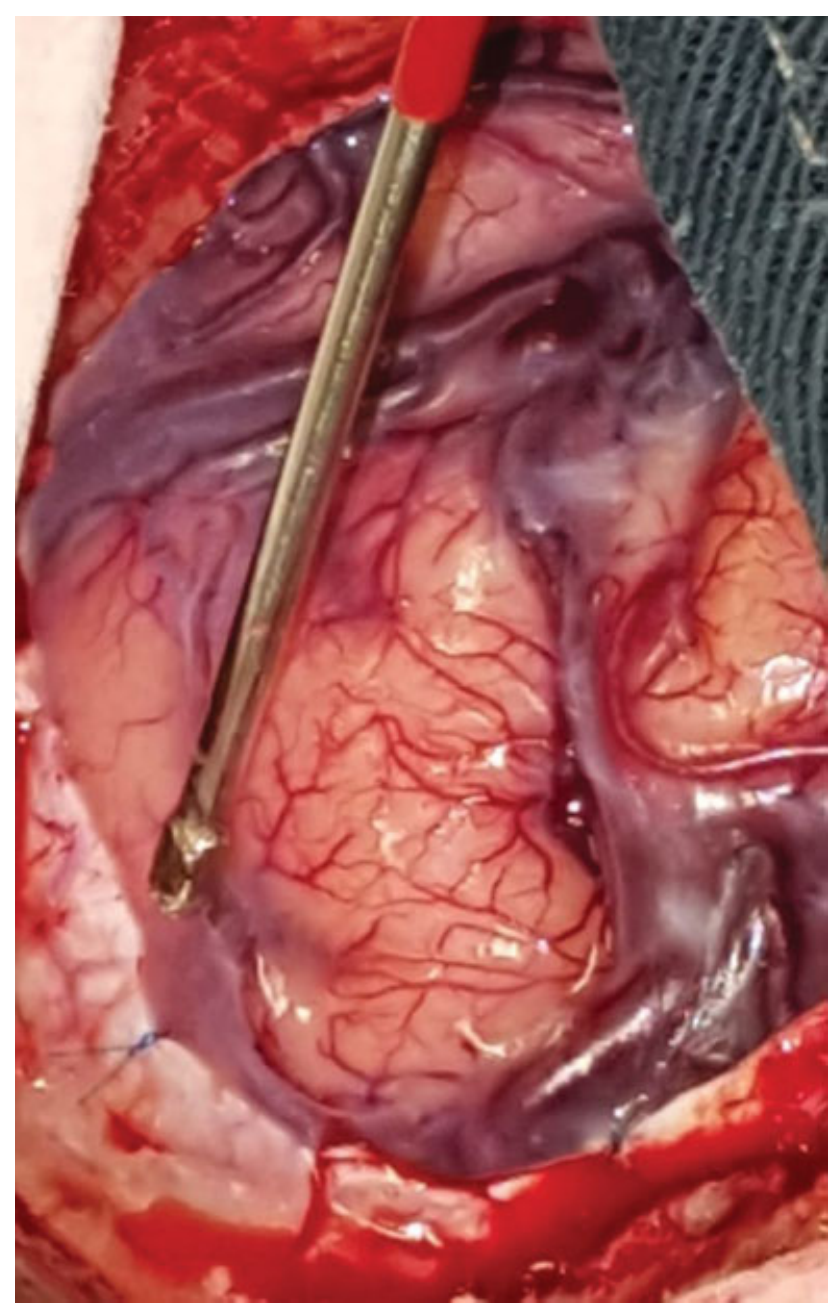

Fig. 1 Frontoparietal craniotomy. The suction tip points to the arachnoid anchorage suture to the dura-mater, close to the craniotomy edge.

executing the trajectory and, finally, in the precise location of the lesion.

However, the method has limitations. The navigation system handpiece tip used by the surgeon at a certain point in the brain correlates with MRI or CT images obtained prior to the surgical procedure. However, during the surgical procedure, the brain moves, either because of gravity or due to relaxation caused by the drainage of CSF (brain shift). Regular systems do not automatically correct for this brain shift and, therefore, the target to be reached. This displacement causes an error in the correlation between the structure shown on the console display and the exact brain region pointed out by the surgeon, making the navigation method inaccurate.

The error caused by brain shift is progressive and depends on several other factors such as head position, cerebral edema, bleeding, use of brain retractors, removal of the lesion and the effects of anesthetic drugs, diuretics or mechanical ventilation.

This correlation accuracy between the neuronavigation and the target structures was studied by Zinreich et al in a replica of the skull made of plastic, and subsequently in three patients. ${ }^{2}$ In the model, the average error between the image and the actual location was between 1 and $2 \mathrm{~mm}$. In surgical cases, the display error between the point shown on the system display and the true anatomical location varied from 0.3 to $2.2 \mathrm{~mm}$.

The error caused by the brain shift was estimated by Golfinos et $\mathrm{al}^{3}$ as being $<2 \mathrm{~mm}$ in $92 \%$ of the navigation systems using MRI images, and in $82 \%$ when CT scans were used. However, over time, the method becomes even more inaccurate. Errors $<2 \mathrm{~mm}$ can be found in $77 \%$ of cases using MRI and in $62 \%$ with CT scan images.

There are several technological solutions to correct the brain shift effects, updating the data obtained in real time. Among them are the electromagnetic systems and those based on ultrasound. However, these systems are not widely available. $^{4}$

The accuracy of neuronavigation systems can be increased by using intraoperative MRI images, which provide real-time data, assessing the effects of brain shift during surgery and documenting residual lesions.

Nimsky et al used intraoperative MRI to quantify and correct brain shift. ${ }^{5}$ There was great variability in measurements, reaching $24 \mathrm{~mm}$ of cortical surface shifting and $>3 \mathrm{~mm}$ in the margins of deep lesions. Of the 64 study participants, intraoperative MRI scans were performed using a 0.2-T device, with an open setup, to correct and update navigation data.

In another study, ${ }^{6}$ Nimsky et al described the use of a microscope integrated with the MRI machine in the operating room. The patients were placed on the MRI machine table with their heads fixed at $\sim 1.5 \mathrm{~m}$ from the center of the magnetic field by a head support made of compatible ceramics. For the acquisition of intraoperative images, the table was slid to the center of the resonance in $<30$ seconds, enhancing the acquisition of intraoperative images to correct for the brain shift.

Brain shifting can be quite distinct according to the brain region of interest. Furthermore, it is a dynamic process. Nabavi et al developed a software (3D Slicer) that makes a quantitative analysis of the degree and direction of the brain shift. ${ }^{7}$ For this, they used a $0.5 \mathrm{~T}$ MRI device, vertically open, which enables the acquisition of multiple intraoperative images without the need to move the patient. With this method, they managed to optimize image acquisition for computational analysis of brain deformations during the surgical procedure.

Marreiros et al assessed a method for measuring and compensating for brain shift in an experimental study in rabbits. ${ }^{8}$ For this, they used superficial blood vessels as reference points. The vessels were displayed by means of infrared cameras aligned with the central point of the vessels seen in the preoperative magnetic resonance angiogram. There was a good correlation between the volume shift seen in the system and the real state of the brain, with $~$ $4 \mathrm{~mm}$ displacements.

Following the same rationale, Jiang et al proposed a method to compensate for the brain shift that integrates vessel and groove sightings, using a phase-change three-dimensional(3D) measurement, which provides direct 2D image pixels and their corresponding 3D points. ${ }^{9}$ The brain surface measurements 
were tracked noninvasively in five pig brains, assessing the shifting caused by gravity or by direct compression.

Sun $\mathrm{H}$ et al developed a method capable of estimating the three-dimensional shape of the brain surface in real time. ${ }^{10}$ They compared the shape with the cortical surface preregistered in the MRI. Cortical displacement was used to guide the whole brain model by updating the volumes obtained by preoperative MRI imaging. According to the authors, the accuracy of this system was $\sim 1 \mathrm{~mm}$.

In a two-part experimental study, Reinertsen et al compared the brain shift correction from intraoperative ultrasound images and preoperative MRI. ${ }^{11}$ In the first part, they tested the technique using realistic simulation, comparing the results with previously measured brain shifts. In the second part of the study, they obtained MRI and ultrasound images from a pva-cryogel phantom model for three different deformations. On average, deformations of a $7.5 \mathrm{~mm}$ magnitude were corrected to $1.6 \mathrm{~mm}$ by the ultrasound recording, and to $1.07 \mathrm{~mm}$ using the MRI data.

The methods described to compensate for the effects of brain shift are sophisticated and are not available in most services.

Our arachnoid anchoring method, hereby described, is simple and easy to perform. The arachnoid anchorage sutures keep the cortical surface closer to the dura mater, decreasing the cortical surface displacement caused by gravity and CSF drainage. It can be used to approach subcortical lesions, minimizing the effects of brain shift vis-à-vis the location of the lesion. Its great merit is to facilitate the location of the lesion, avoiding errors in trajectory and distance from the surface caused by the brain shift. It does not prevent the effects of brain dislocation caused by the progressive exeresis of the lesion; thus, it is not useful for assessing the degree of lesion resection.

\section{Conclusion}

Arachnoid anchorage sutures to the dura near the edges of the cortex area exposed by the craniotomy constitute a simple method to minimize brain displacement (brain-shift) in craniotomies for subcortical lesions, optimizing the usage of the neuronavigation system.

Conflict of Interests

The authors have no conflict of interests to declare.

\section{References}

1 Spetzger U, Laborde G, Gilsbach JM. Frameless neuronavigation in modern neurosurgery. Minim Invasive Neurosurg 1995;38(04): 163-166

2 Zinreich SJ, Tebo SA, Long DM, et al. . Frameless stereotaxic integration of CT imaging data: accuracy and initial applications. Radiology 1993;188(03):735-742

3 Golfinos JG, Fitzpatrick BC, Smith LR, Spetzler RF. Clinical use of a frameless stereotactic arm: results of 325 cases. J Neurosurg 1995;83(02):197-205

4 Ganslandt O, Behari S, Gralla J, Fahlbusch R, Nimsky C. Neuronavigation: concept, techniques and applications. Neurol India 2002;50(03):244-255

5 Nimsky C, Ganslandt O, Cerny S, Hastreiter P, Greiner G, Fahlbusch R. Quantification of, visualization of, and compensation for brain shift using intraoperative magnetic resonance imaging. Neurosurgery 2000;47(05):1070-1079, discussion 1079-1080

6 Nimsky C, Ganslandt O, Kober H, Buchfelder M, Fahlbusch R. Intraoperative magnetic resonance imaging combined with neuronavigation: a new concept. Neurosurgery 2001;48(05):1082-1089, discussion 1089-1091

7 Nabavi A, Black PM, Gering DT, et al. . Serial intraoperative magnetic resonance imaging of brain shift. Neurosurgery 2001; 48(04):787-797, discussion 797-798

8 Marreiros FM, Rossitti S, Wang C, Smedby Ö. Non-rigid deformation pipeline for compensation of superficial brain shift. Med Image Comput Comput Assist Interv 2013;16(Pt 2):141-148

9 Jiang J, Nakajima Y, Sohma Y, Saito T, Kin T, Oyama H, Saito N. Marker-less tracking of brain surface deformations by non-rigid registration integrating surface and vessel/sulci features. Int J CARS 2016;11(09):1687-1701

10 Sun H, Lunn KE, Farid H, et al. . Stereopsis-guided brain shift compensation. IEEE Trans Med Imaging 2005;24(08):1039-1052

11 Reinertsen I, Descoteaux M, Siddiqi K, Collins DL. Validation of vessel-based registration for correction of brain shift. Med Image Anal 2007;11(04):374-388 